University of Rhode Island

DigitalCommons@URI

The Rhode Island Current Conditions Index

Economics

$11-2004$

\title{
Rhode Island Current Conditions Index - November 2004
}

Leonard Lardaro

University of Rhode Island, lardaro@uri.edu

Follow this and additional works at: https://digitalcommons.uri.edu/ricci

Part of the Econometrics Commons

Terms of Use

All rights reserved under copyright.

\section{Recommended Citation}

Lardaro, Leonard, "Rhode Island Current Conditions Index -- November 2004" (2004). The Rhode Island Current Conditions Index. Paper 108.

https://digitalcommons.uri.edu/ricci/108

This Article is brought to you for free and open access by the Economics at DigitalCommons@URI. It has been accepted for inclusion in The Rhode Island Current Conditions Index by an authorized administrator of DigitalCommons@URI.For more information, please contact digitalcommons-group@uri.edu. 


\section{Current Conditions I ndex \\ LEONARD LARDARO URI}

Also available online: http:/ / members.cox.net/ lardaro/ current.htm

Volume XI, Number 2

November 2004

\section{Monthly Highlights}

Rhode Island's current recovery continued in November, although its momentum slowed a bit. The Current Conditions Index for November dipped slightly from October's value of 58 to its neutral value of 50 , as only six indicators showed improvement. None of the improving indicators showed very impressive strength.

But current statistics don't tell the entire story, or, for that matter, tell the current story that well. We are in the midst of a period where the national recovery doesn't seem to get the respect it deserves. At the state level, currently available data do not paint a very bright picture, although the apparent absence of strength is partly the result of data that I expect will ultimately be revised to show a brighter economic picture. Nowhere is this more apparent than in the Labor Force and Unemployment Rate data. According to labor market data, Rhode Island's Labor Force shrank by 9,100 compared to last November, a 1.6 percent decline. Typically, declines at that rate only occur only in the worst of times, which we are obviously not experiencing at present. While our Unemployment Rate appears to have declined dramatically,

\begin{tabular}{lr}
\multicolumn{2}{c}{ CCI Indicators - \% Change } \\
Government Employment & 0.2 Y \\
US Consumer Sentiment & -0.9 \\
Single-Unit Permits & -21.1 \\
Retail Sales & $2.3 \mathbf{Y}$ \\
Help Wanted Advertising & $2.5 \mathbf{Y}$ \\
Priv. Serv-Prod Employment & $1.3 \mathrm{Y}$ \\
Man-Hours Manufacturing & -2.0 \\
Manufacturing Wage & $0.6 \mathrm{Y}$ \\
Labor Force & -1.6 \\
Benefit Exhaustions & 4.4 \\
New Claims & 6.6 \\
Unemployment Rate & $-13.7 \mathbf{Y}$ \\
\multicolumn{1}{|c}{ Y = I mproved Value } &
\end{tabular}

from 5.1 percent last November to 4.4 percent this November, according to labor market data, this occurred with 5,000 fewer Rhode Islanders working! I strongly suspect that our Labor Force is either not declining at present, or that it is falling much more slowly than what the data say. Similarly, while I believe our Unemployment Rate is improving, published rates appear to be too low. We will "officially" see if these conjectures are correct in February.

October's $\mathrm{CCl}$ was revised downward, as two indicators that had shown improvement last month were changed with data revisions. Government Employment actually fell slightly in
October. However, it rose by 0.2 percent in November. The other indicator revised from last month was Manufacturing Man-hours, which was changed to be consistent with its continuing decline. That indicator has only improved once in the last twelve months. Along with declining Manufacturing Man-hours, Manufacturing Wage growth continued to decelerate, displaying its slowest rate in over a year $(+0.6 \%$ on a year-over-year basis), keeping it barely above $\$ 13$.

Retail Sales rose again, by 2.3 percent compared to last November. This occurred as US Consumer Sentiment fell for the first time since May. And, Private Service-Producing Employment growth accelerated slightly to 1.3 percent in November, allowing it to sustain growth well above what we experienced during its "weak patch" from April through June.

Benefit Exhaustions, a measure of long-term unemployment, rose by 4.4 percent, only the second time this indicator has failed to improve at a double-digit rate since April. Layoffs, as measured by New Claims, also failed to improve in November, the fourth time this has occurred in the last six months. This was consistent with a slowing in the rate of growth in labor demand, based on Help Wanted Advertising (which I have adjusted to account for the growing importance of Internet advertising). Finally, the recent strange behavior of Single-Unit Permits continued in November, falling by 21.1 percent compared to last November.

My econometric adjustment to Help Wanted Advertising values has resulted in a series of upward adjustments to $\mathrm{CCl}$ values for 2003 and 2004. Most of the values in the table below have been increased as the result of this change.

\section{Current Conditions Index}

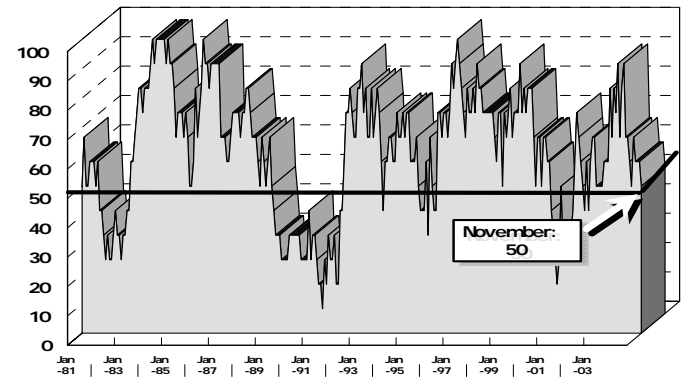

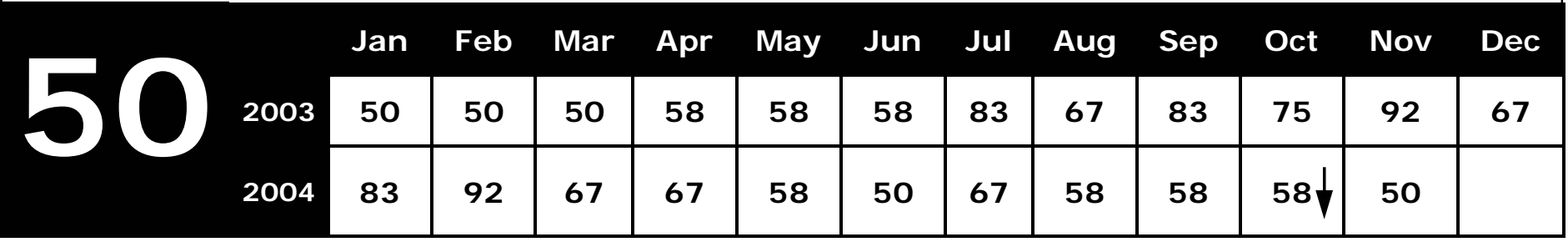

